\title{
DASAR-DASAR KEBIJAKAN KURIKULUM DI MADRASAH IBTIDAIYAH
}

\author{
M. Bustanul Ulum \\ Mar'atus Sholihah \\ Institut Agama Islam Al-Falah As-Sunniyyah Kencong-Jember \\ marmarapgmi@inaifas.ac.id
}

\begin{abstract}
Curriculum policies that change frequently are influenced by one basis that dominates and affects other policy bases. Political basis is the main key in curriculum development in madrasah ibtidaiyah (elementary school) in order to succeed its education process. The basic curriculum policies in madrasah ibtidaiyah does not only consist of philosophical, psychological, sociological, scientific and technological developments, organizational, and political, but are also closely related to the basis of religion as part of an institution that teaches religious education through formal education. This religious basis is important to be embedded in madrasah ibtidaiyah curriculum as an effort to answer modern problems regarding to the behavior of children and adolescents, especially children. The provision of a religious foundation carried out since childhood is believed to be able to strengthen the formation of good behavior (good morals), as has been implemented by Islamic basic education institutions (madrasah ibtidaiyah) so far by teaching religious subjects separately using the broad fields curriculum design.
\end{abstract}

Keywords: policy, curriculum, religion, madrasah ibtidaiyah, child

\begin{abstract}
Abstrak
Kebijakan kurikulum yang sering berubah dipengaruhi oleh salah satu dasar yang mendominasi dan mempengaruhi dasar kebijakan lain. Dasar politik menjadi kunci utama dalam pengembangan kurikulum di madrasah ibtidaiyah untuk menyukseskan proses pendidikan jenjang dasar. Dasar kebijakan kurikulum di madrasah ibtidaiyah tidak hanya terdiri dari dasar filosofis, psikologis, sosiologis, perkembangan IPTEK, organisatoris, dan politik, namun juga sangat lekat dengan dasar agama sebagai bagian dari lembaga yang mengajarkan pendidikan agama melalui pendidikan formal. Dasar agama ini menjadi penting untuk disematkan dalam kurikulum madrasah ibtidaiyah sebagai upaya menjawab permasalahan moderen tentang perilaku anak dan remaja, terutama anak. Pemberian fondasi agama yang dilakukan sejak masa anak-anak dipercayai mampu memperkuat pembentukan perilaku baik (akhlak baik), seperti yang telah diimplementasikan oleh lembaga pendidikan dasar Islam (madrasah ibtidaiyah) selama ini dengan mengajarkan mata pelajaran-mata pelajaran agama secara terpisah dengan menggunakan model the broad fields curriculum design.
\end{abstract}

Kata kunci: kebijakan, kurikulum, agama, madrasab ibtidaiyah, anak 
Mar'atus Sholihah

M. Bustanul Ulum

Pendahuluan

Pendidikan tidak dapat dipisahkan dari kehidupan, Prof. Rupert. C. Lodge mengemukakan "in this scene, life is education, and education is life". Kata-kata tersebut mengungkapkan bahwa seluruh kehidupan memiliki nilai pendidikan, karena kehidupan memberikan pengaruh kepada pendidikan bagi seseorang atau masyarakat. ${ }^{1}$ Seorang tokoh pendidikan pembebasan, yaitu Paulo Freire menyatakan jika pendidikan harus berorientasi pada pengenalan realitas diri manusia dan dirinya sendiri. Pendidikan yang diharapkan menjadi sarana dalam rangka mencapai tujuan hidup manusia harus tersusun secara "apik dan metodik" sebagaimana dalam bentuk kurikulum.

Pendidikan di Indonesia memiliki banyak kebijakan. Kenyataan bahwa kebijakan pendidikan tersebut seringkali berganti dengan cepat, salah satunya dipengaruhi oleh faktor politik. Politik memang tidak bisa dipisahkan dari proses perumusan dan implementasi kebijakan, sebagaimana Tilaar dan Nugroho mengungkapkan bahwa sebagai sebuah strategi, dalam kebijakan publik sudah terangkum preferensi-preferensi politis dari para aktor yang terlibat dalam proses kebijakan, khususnya pada proses perumusan. Kebijakan pendidikan sebagai bagian dari kebijakan publik tidak terlepas dari preferensi politis pemerintah sebagai aktor yang merumuskan kebijakan.

Usia anak-anak merupakan periode awal yang paling penting dalam memperoleh pendidikan dan merupakan hal mendasar sepanjang rentang pertumbuhan dan perkembangan kehidupan manusia. Keseluruhan potensi berkembang sangat cepat pada usia anak-anak. Fakta yang ditemukan oleh ahli-ahli neurologi menyatakan, bahwa sekitar 50\% kapasitas kecerdasan manusia telah terjadi ketika usia 4 tahun dan $80 \%$ telah terjadi ketika berusia 8 tahun. Pertumbuhan fungsional sel-sel saraf tersebut membutuhkan berbagai situasi pendidikan yang mendukung, baik situasi pendidikan keluarga, masyarakat maupun sekolah. Pemerintah sudah mengembangkan kurikulum madrasah ibtidaiyah dan perangkatnya yang dijadikan acuan bagi penyelenggaraan pendidikan jenjang MI (madrasah ibtidaiyah) dalam rangka memenuhi kebutuhan pendidikan anak-anak. Kurikulum MI hendaknya disusun berdasarkan landasan teoritis, yuridis, empiris, dan berdasarkan kebijakan yang telah dirumuskan. Kurikulum pendidikan dikembangkan berdasarkan kompetensi dasar (competency-based curriculum). Sidi mengatakan bahwa kurikulum disusun berdasarkan kemampuan dasar minimal ynag harus

${ }^{1}$ A. Heris Hermawan, Filsafat Pendidikan Islam (Jakarta: Direktorat Jenderal Pendidikan Islam Departemen Agama RI, 2009), 78

2 | Jurnal Auladuna 
dikuasai seorang peserta didik setelah yang bersangkutan menyelesaikan satu unit pelajaran, satu satuan waktu dan satu satuan pendidikan. ${ }^{2}$

Arah reformasi dalam mewujudkan pengembangan pendidikan terkait dengan kebijakan kurikulum MI adalah ikut diperbaharuinya kurikulum yang ada sebelumnya dari kurikulum 1994 yang diperbaharui menjadi kurikulum 2004 atau KBK (Kurikulum Berbasis Kompetensi). Dua tahun kemudian KBK pun telah mengalami pembaharuan kembali menjadi KTSP (Kurikulum Tingkat Satuan Pendidikan) atau kurikulum 2006, dan sekarang menjadi Kurikulum 2013. Sekolah-sekolah diwajibkan untuk melaksanakan Kurikulum 2013 yang berdasarkan Surat Edaran (SE) No. 156928/MPK.A/KR/2013 tentang Implementasi Kurikulum 2013 tertanggal 8 November 2013 dari Kementerian Pendidikan dan Kebudayaan (Kemendikbud). SE tersebut juga mengatur penyediaan buku teks pelajaran untuk pegangan siswa dan guru.

\section{Pembahasan}

\section{Pengertian Kebijakan}

Kebijakan merupakan terjemahan dari kata policy yang berasal dari bahasa Inggris. Kata policy diartikan sebagai sebuah rencana kegiatan atau pernyataan mengenai tujuan-tujuan yang diajukan atau diadopsi oleh suatu pemerintahan, dan partai politik. Kebijakan juga diartikan sebagai pernyataan-pernyataan mengenai kontrak penjaminan atau pernyataan tertulis. ${ }^{3}$ Pengertian ini mengandung arti bahwa yang disebut kebijakan adalah mengenai suatu rencana, pernyataan tujuan, kontrak penjaminan dan pernyataan tertulis baik yang dikeluarkan oleh pemerintah, partai politik, dan lain-lain.

James E. Anderson memberikan pengertian kebijakan sebagai serangkaian tindakan yang mempunyai tujuan tertentu dan diikuti serta dilaksanakan oleh seorang pelaku atau sekelompok pelaku guna memecahkan suatu masalah tertentu. ${ }^{4}$ James E. Anderson secara lebih jelas menyatakan bahwa yang dimaksud dengan kebijakan adalah kebijakan dari hasil pengembangan oleh badan-badan dan pejabat-pejabat pemerintah. Implikasinya antara lain: (1) kebijakan selalu mempunyai tujuan tertentu atau merupakan tindakan yang berorientasi pada tujuan; (2)

\footnotetext{
${ }^{2}$ Sidi, Menuju Masyarakat Belajar: Menggagas Paradigma Baru Pendidikan (Jakarta: Logos Wacana Ilmu, 2001), 15

3 AS. Hornby, Oxford Advanced Learner's Dictionary of Current English, cet. ke-5. (Oxford: Oxford University Press, 1995), 893

${ }^{4}$ James E. Anderson, Public Policy Making, cet. ke-3 (New York: Holt, Rinehart and Winston, 1984), 3 Jurnal Auladuna| 3
} 
Mar'atus Sholihab

M. Bustanul Ulum

kebijakan berisi tindakan-tindakan atau pola-pola tindakan pejabat-pejabat pemerintah; (3) kebijakan merupakan apa yang benar-benar dilakukan oleh pemerintah; (4) kebijakan bisa bersifat positif, dalam arti merupakan beberapa bentuk tindakan pemerintah mengenai suatu masalah tertentu atau bersifat negatif yang merupakan keputusan pejabat pemerintah untuk tidak melakukan sesuatu; (5) kebijakan dalam arti positif didasarkan pada peraturan perundangundangan dan bersifat memaksa (otoritatif). ${ }^{5}$

Heclo menggunakan istilah kebijakan secara luas, yakni sebagai rangkaian tindakan pemerintah atau tidak bertindaknya pemerintah atas sesuatu masalah, baik yang lebih luas dari tindakan atau keputusan yang bersifat khusus. Definisi tersebut diklasifikasikan sebagai decision making, yaitu apa yang dipilih oleh pemerintah untuk mengatasi suatu masalah publik dengan cara melakukan suatu tindakan maupun untuk tidak melakukan suatu tindakan. ${ }^{6}$

Kebijakan sebaiknya dipahami sebagai serangkaian kegiatan yang sedikit banyak berhubungan, beserta konsekuensi-konsekuensinya bagi mereka yang bersangkutan daripada sebagai suatu keputusan tersendiri. Kebijakan dipahami sebagai arah atau pola kegiatan dan bukan sekadar suatu keputusan untuk melakukan sesuatu. Definisi lain diartikan sebagai intervensi negara dengan rakyatnya dalam rangka mengatasi persoalan publik, karena melalui hal tersebut akan terjadi perdebatan antara yang setuju dan tidak setuju terhadap suatu hasil kebijakan yang dibuat oleh pemerintah. ${ }^{7}$

\section{Pengertian Kurikulum}

Istilah "kurikulum" memiliki berbagai tafsiran yang dirumuskan oleh pakar-pakar dalam bidang pengembangan kurikulum. Tafsiran-tafsiran tersebut berbeda-beda antara satu dengan lainnya, sesuai dengan titik berat inti dan pandangan dari pakar-pakar tersebut. Istilah kurikulum berasal dari bahasa Latin, yakni "Curricula", artinya jarak yang harus ditempuh oleh seorang pelari. Pengertian kurikulum kaitannya dengan pendidikan ialah jangka waktu pendidikan yang harus ditempuh oleh siswa yang bertujuan untuk memperoleh ijazah. Siswa dapat memperoleh ijazah dengan menempuh suatu kurikulum. Ijazah pada hakikatnya merupakan suatu bukti, bahwa siswa telah menempuh kurikulum yang berupa rencana pelajaran, sebagaimana halnya seorang pelari telah menempuh suatu jarak antara satu tempat ke

\footnotetext{
${ }^{5}$ Ibid.

${ }^{6}$ Hessel Nogi S. Tangkilisan, Teori dan Konsep Kebijakan Publik: Kebijakan Publik yang Membumi, Konsep, Strategi dan Kasus (Yogyakarta: Lukman Offset dan YPAPI, 2003), 3

${ }^{7}$ Budi Winarno, Apakah Kebijakan Publik ?: Teori dan Proses Kebijakan Publik (Yogyakarta: Media Pressindo, 2002), 15

4 | Jurnal Auladuna
} 
tempat lain dan akhirnya mencapai garis finish. Kurikulum dianggap sebagai jembatan yang sangat penting untuk mencapai titik akhir dari suatu perjalanan dan ditandai oleh perolehan suatu ijazah tertentu. ${ }^{8}$

Kurikulum dalam bahasa Arab diungkapkan dengan manbaj, berarti jalan yang dilalui oleh manusia pada berbagai bidang kehidupan. Kurikulum pendidikan (manhaj al-dirasah) dalam kamus Tarbiyah adalah seperangkat perencanaan dan media yang dijadikan acuan oleh lembaga pendidikan dalam mewujudkan tujuan-tujuan pendidikan. ${ }^{9}$ Mochtar Buchori mengatakan bahwa kurikulum sebagai blue print (cetak biru), yaitu suatu penggambaran terhadap sosok manusia yang diharapkan akan tumbuh setelah menjalani semua proses pendidikan, pengajaran dan pelatihan yang digariskan dalam kurikulum. ${ }^{10}$

Schubert berpendapat sederhana bahwa kurikulum sebagai mata pelajaran, muatan hasil belajar, adanya unsur reproduksi kebudayaan dan pembangunan sosial, serta pentingnya kecakapan hidup. ${ }^{11}$ Zamroni memiliki pernyataan bahwa kurikulum merupakan seperangkat rancangan nilai, pengetahuan dan keterampilan yang harus ditransfer kepada peserta didik dan bagaimana proses transfer tersebut harus dilaksanakan. ${ }^{12}$ Nasution mengemukakan, kurikulum merupakan suatu cara untuk mempersiapkan anak agar berpartisipasi sebagai anggota yang produktif dalam masyarakatnya. ${ }^{13}$

Pengertian kurikulum berkembang sesuai dengan perkembangan teori dan praktik pendidikan, bervariasi sesuai dengan aliran atau teori pendidikan yang dianut. MacDonald mengungkapkan jika kurikulum merupakan suatu rencana yang memberikan pedoman atau pegangan dalam proses kegiatan belajar mengajar. ${ }^{14}$ UU Sisdiknas No. 20 Tahun 2003 mendefinisikan kurikulum sebagai seperangkat rencana dan pengaturan mengenai tujuan, isi, dan bahan pelajaran, serta cara yang digunakan sebagai pedoman penyelenggaraan kegiatan pembelajaran untuk mencapai tujuan pendidikan tertentu. ${ }^{15}$

\footnotetext{
${ }^{8}$ Oemar Hamalik, Kurikulum dan Pembelajaran (Jakarta: Bumi Aksara, 2007), 16

${ }^{9}$ Susanto Santawi, "Pengertian Kurikulum Menurut Para Ahli," Optik Anto, 9 Juni 2012, http://gontor2007.blogspot.com/2012/06/pengertian-kurikulum-menurut-para-ahli.html (diakses 1 Oktober, 2020)

${ }^{10}$ Ibid., 26

${ }^{11}$ Ella Yulaelawati, Kurikulum dan Pembelajaran: Filosofi, Teori dan Aplikasi (Bandung: Pakar Raya, 2004), 25

${ }^{12}$ Zamroni, Paradigma Pendidikan Masa Depan (Yogyakarta: BIGRAF Publishing, 2000), 129

${ }^{13}$ S. Nasution, Azas-Azas Kurikulum (Jakarta: Bumi Aksara, 2003), 7

${ }^{14}$ Nana Sukmadinata, Pengembangan Kurikulum Teori dan Praktik (Bandung: Remaja Rosdakarya, 2008), 4

${ }^{15}$ Undang-undang Republik Indonesia Nomor 20 Tahun 2013 Tentang Sistem Pendidikan Nasional, Pasal 1 Ayat 19
} 
Mar'atus Sholihab

M. Bustanul Ulum

Istilah "kurikulum" di Indonesia boleh dikatakan baru populer sejak tahun 50-an, dipopulerkan oleh mereka yang memperoleh pendidikan di Amerika Serikat. Istilah itu kini telah dikenal orang di luar pendidikan, karena pada hakikatnya, kurikulum sama artinya dengan rencana pelajaran. ${ }^{16}$ Kurikulum madrasah ibtidaiyah sama dengan kurikulum SD (Sekolah Dasar), tetapi pada kurikulum MI terdapat porsi lebih banyak mengenai pendidikan agama Islam.

Madrasah ibtidaiyah selain mengajarkan mata pelajaran sebagaimana sekolah dasar, juga ditambah dengan pelajaran-pelajaran, seperti:
a. Al-Qur'an dan Hadits (Al-Qur'an Hadis)
b. Aqidah dan Akhlaq (Akidah Akhlak)
c. Fiqih (Fikih)
d. Sejarah Kebudayaan Islam
e. Bahasa Arab

f. Ke-NU-an/ Ke-Muhammadiyah-an

Proses pengembangan kurikulum madrasah ibtidaiyah (MI) selain menjadi tanggung jawab internal madrasah, juga harus didukung oleh perhatian yang serius dari proses pembangunan pemerintah. Peningkatan dan pengembangan peran serta madrasah dalam proses pembangunan merupakan langkah strategis dalam membangun masyarakat, daerah, bangsa, dan negara dengan kondisi yang tengah mengalami krisis degradasi moral. Madrasah sebagai lembaga pendidikan yang membentuk dan mengembangkan nilai-nilai moral, harus menjadi pelopor sekaligus inspirator pembangkit moral bangsa. Pembangunan tidak menjadi hampa melainkan lebih bernilai dan bermakna, ${ }^{17}$ maka daripada itu dibutuhkan pengembangan kurikulum lebih serius di madrasah ibtidaiyah yang menjadi lembaga berasaskan dan bernapaskan ilmu agama.

\section{Dasar-dasar Kebijakan Kurikulum di Madrasah Ibtidaiyah}

Madrasah ibtidaiyah di Indonesia sangat unik dan tidak sama dengan madrasah di mana pun, karena: (a) diselengarakan seperti sekolah biasa; (b) mengajarkan kurikulum nasional; (c) menyiapkan siswa untuk mengikuti ujian nasional; (d) bersifat koedukasi; (e) memberikan keterampilan hidup untuk menjadi warga negara yang produktif dalam masyarakat moderen

\footnotetext{
${ }^{16}$ S. Nasution, Asas-Asas Kurikulum..., 2

17 Syelvyana Rosida, "Pengembangan Kurikulum MI di Indonesia," Laysan Poetry, 27 Desember 2012, http://laylil.blogspot.com/2012/12/pengembangan-kurikulum-mi.html (diakses 1 Oktober, 2020)

6 | Jurnal Auladuna
} 
dan majemuk; dan (f) berhasil memberikan landasan nilai dan norma tradisional agama yang kuat berbasis ajaran agama Islam, di samping pendidikan umum. ${ }^{18}$

Nasution menyatakan bahwa pendidikan sebagai sarana mencetak manusia ungggul, maka membutuhkan kurikulum yang sesuai dan tepat, yang berasaskan filosofis, dasar psikologis, dasar sosiologis, dasar organisatoris, dan perkembangan IPTEK sebagai cara untuk menjawab tantangan saat ini dan masa yang akan datang. ${ }^{19}$

\section{a. Dasar Filosofis}

Filsafat yang digunakan sebagai landasan kurikulum adalah filsafat pendidikan. Filsafat dari John Dewey dan teori pendidikan merupakan pertimbangan penting dalam pembuatan kurikulum. Dewey menyatakan bahwa pendidikan merupakan reorganisasi dan rekonstruksi konstan dari pengalaman. Belajar dari pengalaman adalah bagaimana menghubungkan pengalaman kita dengan pengalaman masa lalu dan yang akan datang. Sekolah sebagai lingkungan khusus hendaknya memberikan pengalaman sosial, dengan cara mendorong kegiatan-kegiatan bersifat intrinsik dalam suatu arah sesuai dengan kebutuhan masyarakat, melalui imitasi, persaingan sehat, kerja sama dan memperkuat kontrol.

\section{b. Dasar Psikologis}

Bidang psikologi yang mendasari pengembangan kurikulum yaitu psikologi perkembangan dan psikologi belajar.

1) Psikologi Perkembangan

Perkembangan anak adalah perkembangan seluruh aspek kepribadiannya, tempo dan irama perkembangan masing-masing anak pada setiap aspek tidak selalu sama. Teori perkembangan diharapkan tidak membingungkan para guru, tetapi justru akan memperluas dan memperkaya pengetahuan para pemakai teori-teori perkembangan anak. Tiga teori atau pendekatan tentang perkembangan individu yang dikenal yaitu pendekatan pentahapan, pendekatan diferensial dan pendekatan ipsatif. Pendekatan yang banyak dianut adalah pendekatan pentahapan, pendekatan ini lebih jelas menggambarkan proses ataupun urutan perkembangan individu.

${ }^{18}$ Syam's Blog, "Potret Madrasah Ibtidaiyah di Indonesia: Menyoal Revitalisasi Madrasah Ibtidaiyah di Era Otonomisasi Daerah," Minority Report, 25 Juni 2011, http://myownreport.wordpress.com/2011/06/25/4/ (diakses 1 Oktober, 2020)

${ }^{19}$ S. Nasution, Azas-Azas Kurikulum..., 18 
J.J. Rousseau menyatakan jika perkembangan anak mempunyai empat tahapan, yaitu: masa bayi, masa kanak-kanak, masa remaja, dan masa dewasa. Piaget, Kohlberg dan Erikson merupakan tokoh-tokoh pentahapan anak yang bersifat khusus.

2) Psikologi Belajar

Studi tentang bagaimana individu belajar adalah psikologi belajar. Belajar dapat diartikan sebagai perubahan tingkah laku dan pola pikir yang terjadi melalui pengalaman. Perubahan itu dapat berarah kognitif, afektif maupun psikomotorik, baik terjadi karena pengaruh dari nilai intrinsik ataupun ekstrinsik.

Teori belajar yang banyak kita dikenal antara lain: teori psikologi humanisme, psikologi naturalisme, teori apersepsi (herbartisme), teori S-R, teori belajar goal insight dan teori belajar cognitive. Teori belajar dijadikan dasar bagi proses belajar, maka hubungan yang erat antara kurikulum dan psikologi belajar dan psikologi anak yang terjalin diharapkan mampu menghasilkan pribadi anak yang kokoh.

\section{c. Dasar Sosiologis}

Masyarakat termasuk faktor penting dalam penyusunan dan pengembangan kurikulum, mengingat manusia sebagai makhluk sosial tak dapat hidup tanpa manusia lain ataupun masyarakat lain. Lingkungan masyarakat masing-masing memiliki sistem sosial budaya berbeda. Sistem sosial budaya mengatur pola kehidupan dan pola hubungan antar anggota masyarakat dan antar anggota masyarakat dengan lembaga masyarakat serta antar lembaga masyarakat. Aspek yang cukup penting dalam sistem sosial budaya adalah tatanan nilai-nilai. Tatanan nilai merupakan seperangkat ketentuan, aturan, hukum, dan moral yang mengatur cara berkehidupan dan berperilaku warga masyarakat. Nilai-nilai tersebut bersumber dari agama, budaya, politik, maupun dari segi-segi kehidupan lainnya.

Taylor, dalam Nana Syaodih Sukmadinata menyatakan bahwa kebudayaan merupakan keseluruhan yang kompleks, meliputi: pengetahuan, kepercayaan, kesenian, hukum, moral, adat istiadat, serta kemampuan dan kebiasaan yang diperoleh manusia sebagai anggota masayarakat. Sukmadinata menuliskan bahwa kehidupan masyarakat tidak dapat terlepas dari tempat masyarakat itu sendiri. Lingkungan alam dan keadaan geografis mempengaruhi perilaku dan pola hidup anggota masyarakat, oleh karena itu, konsep pedidikan bersifat nasional dan universal, tetapi pelaksanaan pendidikan bersifat lokal, disesuaikan dengan situasi dan kondisi masyarakat setempat. ${ }^{20}$

${ }^{20}$ Ibid., 54

8 | Jurnal Auladuna 


\section{d. Dasar Organisatoris}

Dasar organisatoris menyangkut tentang bentuk dan bahan yang disajikan dalam pembelajaran. Bentuk berupa mata pelajaran yang terpisah-pisah, atau adanya kaitan antar mata pelajaran, misalnya bentuk the broad fields curriculum design atau bidang studi seperti IPA, IPS, Bahasa, Agama, dan matematika. Cara menghubungkannya adalah dengan menghapus segala batas-batas mata pelajaran, dalam bentuk kurikulum terpadu atau Kurikulum 2013. Ilmu jiwa Gestalt mengutamakan keseluruhan, karena keseluruhan itu lebih bermakna dan lebih relevan dengan kebutuhan anak dan masyarakat. Gestalt cenderung memilih kurikulum terpadu atau integrated curriculum. Ilmu jiwa asosiasi berpendirian lain, bahwa keseluruhan sama dengan jumlah bagian-bagian dan cenderung memilih kurikulum subject centered yang berpusat pada mata pelajaran.

Pernyataan S. Nasution bahwa tidak ada kurikulum terbaik dan terburuk. Setiap organisasi kurikulum mempunyai kebaikan, akan tetapi tidak lepas dari kekurangan yang ditinjau dari segi-segi tertentu. Bermacam-macam organisasi kurikulum dapat dijalankan secara bersama pada suatu sekolah, bahkan yang satu dapat membantu atau melengkapi lainnya. ${ }^{21}$

\section{e. Dasar Perkembangan IPTEK}

Perkembangan ilmu pengetahuan dan teknologi yang ditunjukkan dengan perubahan revolusi industri mencerminkan bahwa ilmu pengetahuan dan teknologi terus berkembang dari masa ke masa, dari abad ke abad, dari tahun ke tahun, bahkan dalam hitungan detik terus berubah. Para ahli sering membuat pernyataan bahwa ilmu bukan hanya untuk ilmu. Pengembangan suatu ilmu pengetahuan tidak hanya ditujukan kepada perkembangan ilmu pengetahuan itu sendiri, melainkan juga diharapkan dapat memberikan sumbangan kepada bidang-bidang kehidupan ataupun kepada ilmu lain. Sumbangan berupa penggunaan dan penerapan suatu bidang ilmu pengetahuan terhadap bidang-bidang lain disebut teknologi. Alisyahban menulis pernyataan Sukmadinata, bahwa teknologi ialah cara melakukan sesuatu untuk memenuhi kebutuhan manusia dengan bantuan alat dan akal (bardware and software) sehingga memperkuat, membuat lebih ampuh, seakan-akan memperpanjang panca indra, anggota tubuh, dan otak manusia. ${ }^{22}$

${ }^{21}$ Ibid., 42

${ }^{22}$ Sukmadinata, Pengembangan Kurikulum: Teori dan Praktek (Bandung: PT Remaja Rosdakarya Offset, 2006), 37 
Perkembangan ilmu dan teknologi tidak berarti harus mencari dan menemukan sendiri serta harus memulai dari awal. Waktu akan banyak terbuang apabila cara tersebut ditempuh, sehingga menyebabkan ketertinggalan. Cara lebih tepat dan memungkinkan untuk mengejar ketertinggalan tersebut adalah dengan transformasi teknologi. Transformasi teknologi merupakan suatu proses pengalihan, penerapan, dan pengembangan ilmu pengetahuan dan teknologi secara teratur. Proses pengalihan tidak berarti mengambil dan menerapkan teknologi seperti keadaan aslinya di negara pengembang, tetapi mencakup juga penyesuaian, modifikasi, dan pengembangan lebih lanjut.

B.J. Habibie mengutarakan lima prinsip yang menjadi pegangan dalam transformasi teknologi industri, yaitu: 1) penyelenggaraan pendidikan dan pelatihan di dalam dan di luar negeri untuk menyiapkan para pelaku transformasi; 2) pengembangan konsep yang jelas dan realistis tentang masyarakat yang akan dibangun serta teknologiteknologi yang diperlukan untuk mewujudkannya; 3) teknologi hanya dapat dialihkan, diterapkan, dan dikembangkan lebih lanjut jika benar-benar diterapkan; 4) bangsa yang ingin mengembangkan diri secara teknologis harus berusaha sendiri memecahkan setiap masalahnya; 5) tahap-tahap awal transformasi bahwa setiap negara harus melindungi perkembangan kemampuan nasionalnya, hingga tercapai kemampuan bersaing secara internasional.

\section{f. Dasar Politik}

Landasan politik diperlukan dalam dunia pendidikan, khususnya di negara Indonesia, agar pendidikan yang sedang berlangsung di negara ini mempunyai pondasi atau pijakan yang sangat kuat, karena pendidikan di setiap negara tidak sama. Politik pendidikan, yaitu studi ilmiah tentang aspek politik dalam seluruh kegiatan pendidikan, dapat juga dikatakan studi ilmiah pendidikan tentang kebijaksanaan pendidikan. ${ }^{23}$

Landasan politik ini penting untuk melatih jiwa masyarakat, berbangsa dan bertanah air serta juga dapat dimaknai sebagai suatu studi untuk mengkritisi suatu sistem pemerintahan yang melakukan penyimpangan amanat. Politik pendidikan yang dimaksud termanifestasikan dalam kebijakan-kebijakan strategis pemerintah di bidang pendidikan dan

${ }^{23}$ Suhartono dan Suparlan, Wawasan Pendidikan: Sebuah Pengantar Pendidikan (Yogyakarta: Ar-Ruzz Media, 2008), 103

10 | Jurnal Auladuna 


\section{Dasar-Dasar Kebijakan Kurikulum.}

diaplikasikan dalam kurikulum. Politik pendidikan yang diharapkan adalah politik pendidikan keberpihakan pada rakyat kecil atau miskin.

Keberpihakan tersebut penting, karena hingga hari ini masih banyak orang tua yang tidak mampu menyekolahkan anak-anaknya sampai tingkat dasar sekali pun, masih banyak sekolah yang kekurangan fasilitas atau bahkan tidak memiliki gedung yang representatif atau tidak memiliki ruang belajar sama sekali, masih banyak sekolah yang sangat kekurangan guru pengajar, masih banyak pula guru (honorer) dibayar sangat rendah, sehingga menyebabkan motivasi mengajarnya sangat rendah dan juga masih banyak siswa yang tidak terakses jaringan internet maupun tidak mampu mengaksesnya dikarenakan keterbatasan letak geografis maupun keterbatasan finansial siswa.

Dalam konteks pembangunan demokratisasi dan desentralisasi di Indonesia, peran politik eksekutif dan legislatif untuk memajukan pendidikan begitu besar. Ranah politik dan kekuasaan harus mampu mewujudkan sistem pendidikan yang mencerdaskan dan mencerahkan peradaban bangsa. Tokoh liberalisme pendidikan asal Amerika Latin, Paulo Freire pernah menegaskan bahwa bagaimana pun kebijakan politik sangat menentukan arah pembinaan dan pembangunan pendidikan. Freire memandang politik pendidikan memiliki nilai penting untuk menentukan kinerja pendidikan suatu negara.

Bangsa dengan politik pendidikan buruk memiliki kinerja pendidikan buruk pula, sebaliknya, negara dengan politik pendidikan bagus memiliki kinerja pendidikan bagus. Kebijakan tersebut ditandai dengan dikeluarkannya UU Sistem Pendidikan Nasional No. 20 tahun 2003. Era reformasi menekankan aspek desentralisasi dan demokratisasi. Kewenangan yang semula terletak di pusat dan berjalan secara top-down diubah dengan memberi kewenangan daerah yang lebih luas, sehingga pola yang berjalan adalah bottom-up.

\section{g. Dasar Agama}

As-Syaibani menetapkan salah satu dasar dalam kebijakan kurikulum pendidikan, yaitu dasar agama (religius). Dasar religius, dasar yang ditetapkan dengan nilai-nilai Ilahi yang terdapat pada Al-Qur'an dan As-Sunnah yang merupakan nilai kebenaran mutlak dan universal. ${ }^{24}$ Landasan Pengembangan kurikulum agama di madrasah pada hakikatnya adalah faktor-faktor yang harus diperhatikan dan dipertimbangkan oleh para pengembang

${ }^{24}$ Muhammad Zaini, Pengembangan Kurikulum Konsep Implementasi Evaluasi dan Inovasi (Yogyakarta: Teras, 2009), 8 
Mar'atus Sholihah

M. Bustanul Ulum

kurikulum ketika hendak mengembangkan atau merencanakan suatu kurikulum lembaga pendidikan. $^{25}$

Dalam mengembangkan kurikulum sebaiknya berlandaskan pada Pancasila, terutama sila ke satu, "Ketuhanan Yang Maha Esa". Negara Indonesia menyatakan bahwa kepercayaan dan ketakwaan terhadap Tuhan Yang Maha Esa sesuai dengan agama dan kepercayaan masing-masing individu. Sikap saling menghormati dan bekerjasama antara pemeluk-pemeluk agama dan penganut-penganut kepercayaan yang berbeda-beda sangat perlu dikembangkan dalam kehidupan, sehingga dapat terbina kehidupan yang rukun dan damai. $^{26}$

Terkait dengan pengembangan materi kurikulum, khususnya agama pada jenjang madrasah ibtidaiyah, untuk mata pelajaran Akidah Akhlak ukuran keberhasilan yang diharapkan adalah peserta didik memiliki keyakinan kuat pada agama Islam dalam hidup bersama sebagai partner kehidupan di negara Indonesia yang multi agama dan multi kultur. Harapannya bahwa siswa bisa membina kehidupan yang harmonis dengan berbagai agama dan keyakinan berbeda, sehingga masa depan kehidupan akan cerah. ${ }^{27}$ Mata pelajaran AlQur'an dan Hadits, diharapkan peserta didik dapat memahami keanekaragaman ideologi, latar belakang sosial, etnik, dan sebagainya, sehingga perbedaan dan bahkan pertentangan sekalipun dapat terjembatani melalui nilai-nilai pluralisme dalam Islam. Mata pelajaran fikih, diharapkan peserta didik tetap konsisten menjalankan syariat Islam dalam keadaan apa pun tanpa terpengaruh dengan pergaulan yang beraneka ragam, artinya peserta didik tidak tergoyahkan dalam melaksanakan agama, tetap berpegang teguh pada hukum Islam (seperti halal, haram, makruh,wajib) dan dapat hidup bersama dalam perbedaan.

Mata pelajaran sejarah kebudayaan Islam, peserta didik diharapkan dapat mengambil pelajaran dari perjalanan sejarah umat Islam. Mereka diharapkan mampu memahami dan mengambil hikmah dari sejarah perkembangan umat Islam pada masa awal, masa pertengahan, dan masa moderen Islam di Indonesia serta mampu menerapkannya dalam kehidupan sehari-hari. Pengembangan kurikulum agama Islam di madrasah ibtidaiyah berdasarkan pada prinsp-prinsip yang ada antara lain:

1) Prinsip peningkatan keimanan dan ketakwaan, budi pekerti lubur, dan nilai-nilai budaya.

Keyakinan dan nilai-nilai yang dianut oleh masyarakat berpengaruh pada sikap dan arti

${ }^{25}$ Oemar Hamalik, Dasar-dasar Pengembangan Kurikulum (Bandung: Remaja Rosdakarya, 2008), 57

${ }^{26}$ Ibid., 68

${ }^{27}$ Rahmat Raharjo, Inovasi Kurikulum Pendidikan Agama Islam (Yogyakarta: Magnum Pustaka, 2010), 80 12 | Jurnal Auladuna 
kehidupannya. Keimanan dan ketakwaan, budi pekerti luhur, dan nilai-nilai budaya perlu digali, dipahami, dan diamalkan oleh peserta didik dalam kehidupan sehari-hari. ${ }^{28}$

2) Berpusat pada potensi, perkembangan, kebutuban dan kepentingan peserta didik serta tuntutan lingkungan. Prinsip ini dimaksudkan agar peserta didik menjadi manusia yang beriman dan bertakwa kepada Tuhan Yang Maha Esa, berakhlak mulia, sehat, berilmu, cakap, kreatif, mandiri, dan menjadi warga negara demokratis dan tanggung jawab. ${ }^{29}$

3) Prinsip keseimbangan antara etika, logika, estetika dan kinestetika. Kurikulum hendaknya menaruh perhatian terhadap siswa agar mampu menjaga keseimbangan dalam proses dan pengalaman belajar yang meliputi etika, logika, estetika, dan kinestetika, sehingga siswa akan menjadi seseorang yang terhormat, cerdas, rasional, dan unggul. ${ }^{30}$

4) Prinsip penguatan integritas nasional. Prinsip ini dimaksudkan untuk menanamkan kesadaran bahwa Indonesia adalah negara majemuk, tetapi keanekaragaman itu tidak boleh membuat perpecahan, karena walau pun berbeda tetap satu jua (Bhinneka Tunggal Ika). ${ }^{31}$

5) Prinsip pengetahuan dan teknologi informasi. Kurikulum dikembangkan atas dasar kesadaran bahwa ilmu pengetahuan dan teknologi terus berkembang, sehingga kurikulum mendorong siswa untuk mampu mengikuti dan memanfaatkan secara tepat ilmu pengetahuan dan teknologi tersebut agar siswa memiliki kemampuan untuk berpikir dan belajar dengan baik. ${ }^{32}$

6) Prinsip pengembangan keterampilan hidup. Prinsip ini mengembangkan empat keterampilan yang harus dimiliki oleh setiap peserta didik sesuai dengan kebutuhan lingkungan sekitar, yaitu keterampilan diri (personal skills), keterampilan berpikir rasional (thinking skills), keterampilan akademik (academic skills), keterampilan vokasional (vocational skills). Penguasaan keterampilan tersebut akan membuat siswa setelah lulus sekolah dapat mempertahankan hidupnya sesuai dengan pilihan masing-masing individu. ${ }^{33}$

${ }^{28}$ Muhaimin dkk, Pengembangan Kurikulum Berbasis Kompetensi di Perguruan Tinggi Agama Islam (Yogyakarta: Pustaka Pelajar, 2005), 61

${ }^{29}$ Muhaimin dkk, Pengembangan Model Kurikulum Tingkat Satuan Pendidikan (KTSP) pada Sekolah dan Madrasah (Jakarta: Rajawali Pers, 2008), 21-22

${ }^{30}$ Syaiful Sagala, Konsep dan Makna Pembelajaran (Bandung: Alfabeta, 2010), 116

${ }^{31}$ Ibid.

${ }^{32}$ Mulyasa, Kurikulum Tingkat Satuan Pendidikan (Bandung: Remaja Rosdakarya, 2009), 152

${ }^{33}$ Muhammad Zaini, Pengembangan Kurikulum Konsep Implementasi Evaluasi dan Inovasi (Yogyakarta: Teras, 2009), 117 
7) Prinsip pilar pendidikan. Pilar pendidikan yang dijadikan prinsip pengembangan kurikulum di madrasah ibtidaiyah ada empat, yaitu: learning to know (belajar untuk memahami), learning to do (kemampuan untuk berbuat), learning to be (belajar untuk menjadi), dan learning to live together (belajar untuk hidup bersama).

8) Prinsip kontinuitas (berkesinambungan). Kurikulum disusun secara berkesinambungan, artinya bagian-bagian, aspek-aspek, materi, dan bahan kajian disusun secara berurutan. Pengalaman belajar yang disediakan oleh kurikulum harus memperhatikan kesinambungan (antar kelas, antar jenjang pendidikan, antar jenjang pendidikan dengan jenis pekerjaan)..$^{34}$

9) Prinsip belajar sepanjang hayat. Kurikulum di madrasah ibtidaiyah diarahkan kepada pengembangan, pembudayaan, dan pemberdayaan peserta didik yang berlangsung sepanjang hayat. Kurikulum mencerminkan keterkaitan unsur-unsur pendidikan formal, informal dan nonformal dengan memperhatikan kondisi dan tuntutan lingkungan yang selalu berkembang. ${ }^{35}$

\section{Tahapan-tahapan Kebijakan Kurikulum di Madrasah Ibtidaiyah}

Pembuatan kebijakan kurikulum di tingkat MI bertujuan agar suatu kebijakan dapat disusun dan dilaksanakan dengan baik. Kebijakan yang dimunculkan sebagai sebuah keputusan terlebih dahulu melewati beberapa tahapan penting. Tahapan-tahapan pembuatan kebijakan kurikulum MI sangat diperlukan sebagai upaya melahirkan kebijakan baik dan dapat diterima sebagai sebuah keputusan. Tahapan kebijakan tersebut, antara lain:

\section{Penyusunan Agenda}

Pembuat kebijakan perlu menyusun agenda dengan memasukkan dan memilih masalah-masalah mana saja yang akan dijadikan prioritas untuk dibahas sebelum kebijakan ditetapkan dan dilaksanakan. ${ }^{36}$ Masalah-masalah yang terkait dengan kebijakan akan dikumpulkan sebanyak mungkin untuk diseleksi. Masalah-masalah tersebut dimasukkan dalam agenda untuk dipilih. Jenis masalah bermacam-macam, terdapat masalah yang ditetapkan sebagai fokus pembahasan, masalah yang mungkin ditunda pembahasannya,

\footnotetext{
${ }^{34}$ Muhammad Zaini, Pengembangan Konsep Implementasi Evaluasi dan Inovasi (Yogyakarta: Teras, 2009), 111

${ }^{35}$ Mulyasa, Kurikulum Tingkat Satuan Pendidikan (Bandung: Remaja Rosdakarya, 2009), 153

${ }^{36}$ Robert B. Denhardt dan Janet V. Denhardt, Public Administration: an Action Orientation (Boston: Wadsworth, 2009), 50

14 | Jurnal Auladuna
} 
atau mungkin tidak disentuh sama sekali. Masalah yang dimasukkan atau tidak dimasukkan dalam agenda memiliki argumentasi masing-masing. ${ }^{37}$ Pihak-pihak yang terlibat dalam tahap penyusunan agenda harus secara teliti melihat masalah-masalah mana saja yang memiliki tingkat relevansi tinggi dengan masalah kebijakan, sehingga pemilihan tersebut dapat menemukan masalah dengan kebijakan tepat.

\section{Formulasi Kebijakan}

Masalah yang sudah dimasukkan dalam agenda kebijakan kemudian dibahas oleh pembuat kebijakan dalam tahap formulasi kebijakan. Masalah ditentukan mana yang merupakan masalah yang benar-benar layak dijadikan fokus pembahasan dari berbagai masalah yang muncul. ${ }^{38}$

\section{Adopsi Kebijakan}

Pengadopsian merupakan satu alternatif pemecahan yang disepakati dari sekian banyak alternatif yang ditawarkan untuk digunakan sebagai solusi atas permasalahan tersebut. $^{39}$ Tahap ini sering disebut juga dengan tahap legitimasi kebijakan (policy legitimation), yaitu kebijakan yang telah mendapatkan legitimasi. ${ }^{40}$ Masalah yang telah dijadikan sebagai fokus pembahasan memperoleh solusi pemecahan berupa kebijakan yang nantinya akan diimplementasikan.

\section{Implementasi Kebijakan}

Tahap ini merupakan alternatif pemecahan yang telah disepakati kemudian dilaksanakan, seringkali kebijakan yang sudah disepakati menemukan berbagai kendala. Rumusan-rumusan yang telah ditetapkan secara terencana dapat saja berbeda di lapangan, yang mana penyebabnya muncul dari berbagai faktor dan sering mempengaruhi pelaksanaan kebijakan. Kebijakan yang telah melewati tahapan pemilihan masalah tidak langsung berhasil dalam implementasi. Kendala-kendala yang menjadi penghambat harus mampu diatasi sejak awal dalam rangka mengupayakan keberhasilan implementasi kebijakan.

\section{Evaluasi Kebijakan}

${ }^{37}$ Budi Winarno, Kebijakan Publik: Teori, Proses, dan Studi Kasus (Yogyakarta: Media Pressindo, 2002), 33

${ }^{38}$ Ibid., 34

${ }^{39}$ Ibid.

${ }^{40}$ Robert B. Denhardt dan Janet V. Denhardt, Public Administration: an Action Orientation..., 53 
Kebijakan yang telah dilaksanakan akan dievaluasi, untuk dilihat sejauh mana kebijakan tersebut telah mampu memecahkan masalah atau tidak. Kriteria-kriteria yang menjadi dasar untuk menilai apakah kebijakan telah meraih hasil yang diinginkan harus ditentukan. ${ }^{41}$ Penilaian tidak hanya menilai implementasi dari kebijakan, tetapi penilaian harus menentukan lebih jauh perubahan terhadap kebijakan. Kebijakan dapat tetap seperti semula, diubah atau dihilangkan sama sekali.

\section{Penutup}

Pendidikan bukanlah segalanya, tetapi segala-galanya berawal dari pendidikan. Pendidikan selalu membutuhkan kurikulum yang mampu membawa kepada kesuksesan tujuan pembelajaran. Pendidikan di Indonesia memiliki banyak kebijakan. Kenyataan bahwa kebijakan pendidikan tersebut seringkali berganti dengan cepat, salah satunya dipengaruhi oleh faktor politik. Politik memang tidak bisa dipisahkan dari proses perumusan dan implementasi kebijakan.

Kebijakan (policy) adalah rencana kegiatan atau pernyataan mengenai tujuan-tujuan yang diajukan atau diadopsi oleh suatu pemerintahan dan partai politik. Kurikulum (curricula) merupakan jarak yang harus ditempuh oleh seorang pelari. Manhaj adalah jalan yang dilalui oleh manusia pada berbagai bidang kehidupan. Kurikulum madrasah ibtidaiyah sama dengan kurikulum sekolah dasar, tetapi pada kurikulum madrasah ibtidaiyah terdapat porsi lebih banyak mengenai pendidikan agama Islam, yang terdiri dari: Al-Qur'an dan Hadits, Akidah dan Akhlak, Fikih, Sejarah Kebudayaan Islam, bahasa Arab, Ke-NU-an/ Ke-Muhammadiyah-an.

Kebijakan kurikulum di madrasah ibtidaiyah membutuhkan dasar-dasar dalam pembuatannya, antara lain: dasar filosofis, dasar psikologis, dasar sosiologis, dasar organisatoris, dasar perkembangan IPTEK, dasar agama dan dasar politik. Tahapan-tahapan yang harus digunakan dalam pembuatan kebijakan kurikulum di madrasah ibtidaiyah, yaitu: penyusunan agenda, formulasi kebijakan, adopsi kebijakan, implementasi kebijakan dan evaluasi kebijakan.

\section{Referensi}

1. Anderson, J.E. 1984. Public Policy Making. Cet. ke-3. New York: Holt, Rinehart and Winston.

${ }^{41}$ Winarno, Kebijakan Publik: Teori, Proses, dan Studi Kasus..., 34 16 | Jurnal Auladuna 
Dasar-Dasar Kebijakan Kurikulum.

2. Blog, S. "Potret Madrasah Ibtidaiyah di Indonesia: Menyoal Revitalisasi Madrasah Ibtidaiyah di Era Otonomisasi Daerah", Minority Report, 25 Juni 2011, http://myownreport.wordpress.com/2011/06/25/4/ (diakses 1 Oktober, 2020).

3. Denhardt, R.B. dan Janet V.D. 2009. Public Administration: an Action Orientation. Boston: Wadsworth.

4. Hamalik, O. 2008. Dasar-dasar Pengembangan Kurikulum. Bandung: Remaja Rosdakarya.

5. Hamalik, O. 2007. Kurikulum dan Pembelajaran. Jakarta: Bumi Aksara.

6. Hermawan, A. H. 2009. Filsafat Pendidikan Islam. Jakarta: Direktorat Jenderal Pendidikan Islam Departemen Agama RI.

7. Hornby, AS. 1995. Oxford Advanced Learner's Dictionary of Current English. Cet. ke5. Oxford: Oxford University Press.

8. Muhaimin, et al. 2005. Pengembangan Kurikulum Berbasis Kompetensi di Perguruan Tinggi Agama Islam. Yogyakarta: Pustaka Pelajar.

9. Mulyasa. 2009. Kurikulum Tingkat Satuan Pendidikan. Bandung: Remaja Rosdakarya.

10. Nasution, S. 2003. Azas-Azas Kurikulum. Jakarta: Bumi Aksara.

11. Raharjo, R. 2010. Inovasi Kurikulum Pendidikan Agama Islam. Yogyakarta: Magnum Pustaka.

12. Rosida, S. "Pengembangan Kurikulum MI di Indonesia", Laysan Poetry, 27 Desember 2012, http://laylil.blogspot.com/2012/12/pengembangan-kurikulum-mi.html (diakses 1 Oktober, 2020).

13. Santawi, S. "Pengertian Kurikulum Menurut Para Ahli", Optik Anto, 9 Juni 2012, http://gontor2007.blogspot.com/2012/06/pengertian-kurikulum-menurut-para-ahli.html (diakses 1 Oktober, 2020).

14. Sidi. 2001. Menuju Masyarakat Belajar: Menggagas Paradigma Baru Pendidikan. Jakarta: Logos Wacana Ilmu.

15. Suhartono dan Suparlan. 2008. Wawasan Pendidikan: Sebuah Pengantar Pendidikan. Yogyakarta: Ar-Ruzz Media.

16. Sukmadinata, N. 2008. Pengembangan Kurikulum Teori dan Praktik. Bandung: Remaja Rosdakarya. 
17. Sukmadinata. 2006. Pengembangan Kurikulum: Teori dan Praktek. Bandung: PT Remaja Rosdakarya Offset.

18. Sagala, S. 2010. Konsep dan Makna Pembelajaran. Bandung: Alfabeta.

19. Tangkilisan, H.N.S. 2003. Teori dan Konsep Kebijakan Publik: Kebijakan Publik yang Membumi, Konsep, Strategi dan Kasus. Yogyakarta: Lukman Offset dan YPAPI.

20. Undang-undang Republik Indonesia. Sistem Pendidikan Nasional. Nomor 20 Tahun 2013.

21. Winarno, B. 2002. Apakah Kebijakan Publik ?: Teori dan Proses Kebijakan Publik. Yogyakarta: Media Pressindo.

22. Yulaelawati, E. 2004. Kurikulum dan Pembelajaran: Filosofi, Teori dan Aplikasi. Bandung: Pakar Raya.

23. Zaini, M. 2009. Pengembangan Kurikulum Konsep Implementasi Evaluasi dan Inovasi. Yogyakarta: Teras.

24. Zamroni. 2000. Paradigma Pendidikan Masa Depan. Yogyakarta: BIGRAF Publishing. 